\title{
Occupational exposure to organophosphorus and carbamates in farmers in La Cienega, Jalisco, Mexico: oxidative stress and membrane fluidity markers
}

Joel Salazar-Flores ${ }^{1 \dagger}$, Fermín P. Pacheco-Moisés ${ }^{2 \dagger}$, Genaro G. Ortiz ${ }^{3}$, Juan H. Torres-Jasso ${ }^{4}$, Odette Romero-Rentería ${ }^{1}$, Ana L. Briones-Torres ${ }^{2}$ and Erandis D. Torres-Sánchez ${ }^{1 *}$ (D)

\begin{abstract}
Background: The region of La Cienega in Jalisco Mexico, is an important agricultural reference for the production of corn, sorghum and wheat, among other grains, so the use of pesticides for pest control is high. However, in this rural area there are no toxicological studies that assess the occupational risk of pesticide use. Therefore, this study is the first to determine the oxidative stress levels markers (GSH, GSSG, carbonyl groups, nitric oxide metabolites and lipid peroxides) as well as alteration of the mitochondrial membrane fluidity caused by occupational exposure to organophosphorus and carbamates in farmers of this region. This occupational risk can increase cellular oxidation, which explains the high prevalence of neurodegenerative diseases and cancer in Cienega settlers to be analyzed in future studies.
\end{abstract}

Methods: Comparative cross-sectional study was performed using two groups: one not exposed group $(n=93)$ and another one with occupational exposure $(n=113)$. The latter group was sub-divided into 4 groups based on duration of use/exposure to pesticides. Oxidative stress levels and membrane fluidity were assessed using spectrophotometric methods. Statistical analyses were performed using SPSS software ver. 19.0 for windows.

Results: The most commonly used pesticides were organophosphorus, carbamates, herbicide-type glyphosate and paraquat, with an average occupational exposure time of 35.3 years. There were statistically significant differences in markers of oxidative stress between exposed farmers and not exposed group $(p=0.000)$. However, in most cases, no significant differences were found in markers of oxidative stress among the 4 exposure sub-groups $(p>0.05)$.

\footnotetext{
* Correspondence: erandis.torres@academicos.udg.mx

†Joel Salazar Flores and Fermín P. Pacheco-Moisés contributed equally to this work.

'Department of Medical Sciences and Life, CUCIENEGA, University of Guadalajara, Ocotlan, Jalisco, Mexico

Full list of author information is available at the end of the article
}

C C The Author(s). 2020 Open Access This article is licensed under a Creative Commons Attribution 4.0 International License, which permits use, sharing, adaptation, distribution and reproduction in any medium or format, as long as you give appropriate credit to the original author(s) and the source, provide a link to the Creative Commons licence, and indicate if changes were made. The images or other third party material in this article are included in the article's Creative Commons. licence, unless indicated otherwise in a credit line to the material. If material is not included in the article's Creative Commons licence and your intended use is not permitted by statutory regulation or exceeds the permitted use, you will need to obtain permission directly from the copyright holder. To view a copy of this licence, visit http://creativecommons.org/licenses/by/4.0/ The Creative Commons Public Domain Dedication waiver (http://creativecommons.org/publicdomain/zero/1.0/) applies to the data made available in this article, unless otherwise stated in a credit line to the data. 
(Continued from previous page)

Conclusion: In the Cienega region, despite the indiscriminate use of organophosphorus and carbamates, there are no previous studies of levels oxidative stress. The results show increased levels of oxidative stress in occupationally exposed farmers, particularly membrane fluidity levels increased three times in contrast to not exposed group.

Keywords: Oxidative stress, Organophosphorus, Carbamates, Occupational exposure, Farmers of Cienega, Membrane fluidity

\section{Introduction}

Oxidative stress is an imbalance between reactive oxidant species (ROS) generation and antioxidant species, which results in oxidation of biomolecules [1]. Oxidizing species lose electrons and generate molecules with unpaired electrons called free radicals, which react with other molecules through redox reactions [1]. When the levels of oxidants exceed the levels of antioxidant species, biomolecules become oxidized, resulting in various chronic diseases, neurodegenerative diseases and cancer [2]. Physiologically, the balance between oxidation and antioxidation is mediated by the enzyme glutathione reductase (GR) which converts oxidized glutathione (GSSG) to reduced glutathione (GSH). The GSH is a substrate for glutathione peroxidase (GPx), an enzyme that reduces oxidant species such as hydroperoxides [3]. The organophosphorus compounds (OPs) alter the antioxidant defense and biomembranes lipids, resulting in mitochondrial energy depletion, proteolysis and DNA fragmentation [4]. OPs are highly lipid-soluble, volatile and toxic to non-target organisms, including humans [5]. Some OPs like terbufo are chemically unstable thioether OPs with unpaired electrons [6]. It destabilizes protein and lipid molecules $[7,8]$. The carbofuran is a carbamate pesticide and carbamic acid derivative which stimulates cholinergic hyperactivity and modifies redox potential while decreasing antioxidant status [9]. Consequently, factors that trigger systemic toxicity to pesticides are ROS and reactive nitrogen species (RNS) [911]. The ROS are formed by partial reduction of molecular oxygen, and the main products are superoxide anion $\left(\mathrm{O}_{2}^{-}\right)$and $\mathrm{H}_{2} \mathrm{O}_{2}$ [12-14]. RNS are molecules derived from the chemical reaction between nitric oxide (NO) and $\mathrm{O}_{2}^{-}$to forms peroxynitrite $\left(\mathrm{ONOO}^{-}\right)$releasing nitrite $\left(\mathrm{NO}_{2}{ }^{-}\right)$, nitrate $\left(\mathrm{NO}_{3}{ }^{-}\right)$and $\mathrm{OH}^{-}$groups [15].

Increased in levels of ROS and RNS affect the side groups of proteins and form carbonyl groups. The carbonyl groups react particularly with lysine, cysteine and histidine [16]. This may impact on cysteine groups of GR, thereby interfering with the conversion of GSSG to GSH [3]. Another potential impact of oxidation as a result of occupational exposure to pesticides is reflected in peroxidation of polyunsaturated fatty acids (PUFAs), particularly arachidonic acid, to form products such as malondialdehyde (MDA) and 4-hydroxyalkene (4-HNE) [17]. Increases in products of lipid peroxidation alter the membrane lipids, thereby affecting biophysical parameters such as fluidity, permeability, domains formation, fission-fusion, cellular signals transduction and activities of membrane proteins $[18,19]$, which can alter the level of membrane fluidity important in cellular and mitochondrial integrity. It should be noted that in la Cienega region of Jalisco México, there are no studies that evaluate organophosphorus toxicological damage at membrane fluidity levels. By other side, it is known that $\mathrm{ONOO}^{-}$oxidizes lipids faster than ROS, and it forms peroxynitrosocarbonates which increase the harmful effects mediated by pesticides $[20,21]$. In particular, high occupational exposure to OPs inhibits the enzyme acetylcholinesterase (AChE), leading to over-stimulation of the cholinergic activity and the glutamatergic pathway. Increased glutamate activates N-methyl-D-aspartate (NMDA) receptors which, which in turn stimulate the synthesis of NO $[21,22]$. Moreover, the OPs increase the concentration of intracellular $\mathrm{Ca}^{2+}$ ions, further inducing NO synthesis [22]. The toxicity of carbamate is regulated by a process similar to that of OPs through irreversible inhibition of $\mathrm{AChE}$, with increased oxidative stress. In the study by Liu [23], it was observed that exposure of liver cells to carbamate induced the synthesis of cytotoxic aldehydes (MDA and 4-HNE), acrolein and $\mathrm{H}_{2} \mathrm{O}_{2}$. In addition, the toxicity of paraquat increases the concentration of $\mathrm{H}_{2} \mathrm{O}_{2}$ and $\mathrm{OH}^{-}$radicals, and $\mathrm{H}_{2} \mathrm{O}_{2}$ promotes the formation of disulphide bonds, thereby reducing antioxidant capacity [24].

The aim of this study was to evaluate the indices of oxidative stress (GSH, GSSG, carbonyl groups, NO metabolites and lipid peroxides) and membrane fluidity in farmers with occupational exposure to pesticides, relative to not exposed group without occupational exposure in La Cienega region, Jalisco, Mexico. This region is characterized by the lack of regulation on the sale and application of pesticides [25] and by the absence of toxicological studies that impact on health, so the analysis of oxidative stress levels is a first approach to address the health problems that affect The Cienega region in Jalisco, Mexico. The most widely used pesticides were terbufos (s-tert- 
butylthiomethyl-o, o-diethyl-phosphorodithioate), carbofurans (2,3-dihydro-2,2-dimethyl-7-benzofuranyl methyl carbamate), paraquat (1,1'-dimethyl-4,4'-bipyridyl dichloride), glyphosate [n- (phosphonomethyl) glycine-isopropylamine 1: 1), and fipronil (5-amino-1- (2,6-dichloro- $\alpha, \alpha, \alpha$-trifluoro-p-tolyl) -4- trifluoromethylsulfinylprazole-3-carbonitrile)] [26, 27].

\section{Material and methods}

\section{Study sample}

A total of 113 residents of La Cienega region of Jalisco, Mexico, occupationally exposed to various pesticides, were studied. The average occupational exposure time was 35.3 years, and the subjects were aged 22 to 72 years. Sampling was carried out from 2017 to 2018 in the corn growing months (high exposure period) in 7 agricultural communities of La Cienega region, Jalisco, Mexico. The not exposed group was made up of 93 subjects with an age range between 17 to 28 years and a mean of 23 years, with a $95 \%$ confidence interval, without occupational exposure to pesticides, who are residents of the same geographical area. This project was approved by the Ethics Committee of the University Center of La Cienega, University of Guadalajara (Folio 2017-037). Each participant signed an informed consent letter guaranteeing the confidentiality of data. The study was carried out in strict compliance with the principles of the Declaration of Helsinki.

\section{Processing of the samples}

Blood $(10 \mathrm{ml})$ was taken through venous puncture in two 5 - $\mathrm{mL}$ vials. One of the vials had $0.1 \%$ ethylene diamine tetra acetic acid (EDTA). Plasma, serum and erythrocytes were obtained after centrifugation at $310 \mathrm{~g}$ for $15 \mathrm{~min}$ at $4{ }^{\circ} \mathrm{C}$, and kept at $-80^{\circ} \mathrm{C}$ until used.

\section{Determination of oxidative stress markers and MF Glutathione redox system}

Erythrocyte samples were divided in two fraction for total and oxidized glutathione quantification using an enzymatic recycling procedure. For total glutathione determination, GSH was oxidized to GSSG with 5,5'dithiobis-2-nitrobenzoic acid. Subsequently, GSSG was reduced to GSH in a reaction catalyzed by the enzyme GR, with Nicotinamide Adenine Dinucleotide Phosphate (NADPH) as reductant. The reaction rate of 5,5' -dithiobis-2-nitrobenzene was determined at $412 \mathrm{~nm}$. The other fraction of the samples was treated as above, except that 2 -vinylpyridine was added to remove all GSH. The GSSG levels were subtracted from the total glutathione to determine the GSH level $[28,29]$.

\section{Protein carbonyl levels and metabolites of nitric oxide}

Plasma $(200 \mu \mathrm{L})$ was vortexed with $500 \mu \mathrm{L}$ of $10 \mathrm{mM} \mathrm{2,4-}$ dinitrophenylhydrazine diluted in $2 \mathrm{M} \mathrm{HCl}$. Subsequently, it was incubated for $1 \mathrm{~h}$ at room temperature. Thereafter, $333 \mu \mathrm{L}$ of trichloroacetic acid was added, followed by centrifugation at $14,000 \mathrm{rpm}$ for $20 \mathrm{~min}$. The precipitate was washed three times with $1 \mathrm{~mL}$ of ethanol: ethyl acetate solution (1:1, v: v). To the final precipitate was added $600 \mu \mathrm{L}$ of guanidine hydrochloride, followed by incubation for 15 min at room temperature. The absorbance of the solution was read at $370 \mathrm{~nm}$ [30].

Nitric oxide metabolites were determined by adding 6 mg of zinc sulfate to $400 \mu \mathrm{L}$ of serum, and then centrifuging at $10,000 \mathrm{rpm}$ at $4{ }^{\circ} \mathrm{C}$ for $10 \mathrm{~min}$. To the resultant supernatant was added $100 \mu \mathrm{L}$ of vanadium chloride at a concentration of $8 \mathrm{mg} / \mathrm{mL}$. To reduce the $\mathrm{NO}_{3}{ }^{-}$to $\mathrm{NO}_{2}{ }^{-}$, Griess reagent (comprising $50 \mu \mathrm{L}$ of $2 \%$ sulfanilamide, and $50 \mu \mathrm{L}$ of $0.1 \% \mathrm{~N}$-(1-naphthyl) ethylenediamine dihydrochloride) was added. Following incubation for $30 \mathrm{~min}$ at $37^{\circ} \mathrm{C}$, the absorbance was read at $540 \mathrm{~nm}$ [31].

\section{Lipid peroxide levels and membrane fluidity}

The quantification of MDA and 4-HNE products in plasma was performed using FR12 kits (Oxford Biomedical Research, MI, USA) in line with the manufacturer's protocol. In this assay, the reagent $\mathrm{N}$-methyl-2-phenylindole reacts with MDA and 4- $\mathrm{HNE}$ at $45^{\circ} \mathrm{C}$ to form a chromophore which is determined via absorbance measurement at $586 \mathrm{~nm}$ (Oxford kit).

The fluidity of the plasma membranes was determined in platelets via the incorporation of 1,3 dipyrylpropane (DiPP). In this method, $1 \mathrm{~mL}$ of sample was added to $0.1 \mathrm{nmol}$ of DiPP in $10 \mathrm{mM}$ Tris- $\mathrm{HCl}$ buffer, $\mathrm{pH}$ 7.8. The mixture was incubated in the dark at $4{ }^{\circ} \mathrm{C}$ for $5 \mathrm{~h}$ to ensure incorporation of DiPP. Then, fluorescence was measured at $24^{\circ} \mathrm{C}$ at an excitation wavelength of $329 \mathrm{~nm}$ for the monomer and the excimer; and the emission peaks were read at 379 and $480 \mathrm{~nm}$, respectively. Finally, the excimer/monomer fluorescence ratio of the samples was measured [32].

\section{Statistical analysis}

To calculate the frequency of use of pesticides and values of biomarkers of oxidative stress, descriptive statistics were performed. The results are expressed as frequencies and mean \pm standard deviation, respectively. Student's $t$-test was used to determine significant differences in the values of biomarkers of oxidative stress among the different groups (exposed and unexposed), while ANOVA and Tukey multi-comparative tests were used to compare exposure groups based on the duration of use of pesticides. All statistical analyses were carried out using SPSS Statistical Program v. 19.0 [33]. For each marker, statistical significant of difference was assumed at $p \leq 0.05$. 
Table 1 Frequency of use pesticides in La Cienega de Jalisco México region, and classification

\begin{tabular}{|c|c|c|c|c|}
\hline Pesticide & n (\%) & Type & US EPA & WHO \\
\hline Malathion & $1(0.30)$ & Organophosphorus & $\mathrm{D}$ & II \\
\hline Parathion & $1(0.30)$ & Organophosphorus & C & 1a $\mid A$ \\
\hline Diazinon & $2(0.61)$ & Organophosphorus & $E$ & ॥ \\
\hline Chlorpyrifos-ethyl & $11(3.37)$ & Organophosphorus & C & $\|$ \\
\hline Terbufos & $61(18.7)$ & Organophosphorus & $E$ & IA \\
\hline \multicolumn{5}{|c|}{ Percentage of Organophosphorus $=23.39 \%$} \\
\hline Cypermethrin & $3(0.92)$ & Pyrethroid & C & ॥ \\
\hline Tefluthrin & $6(1.84)$ & Pyrethroid & $\mathrm{NL}$ & 1B \\
\hline Deltamethrin & $2(0.61)$ & Pyrethroid & $\mathrm{NL}$ & $\|$ \\
\hline Cyhalothrin-lambda & $4(1.22)$ & Pyrethroid & $\mathrm{D}$ & ॥ \\
\hline Cypermethrin-alpha & $12(3.6)$ & Pyrethroid & $\mathrm{C}$ & $\|$ \\
\hline \multicolumn{5}{|c|}{ Percentage of pyrethroids $=\mathbf{8 . 1 9} \%$} \\
\hline Carbofuran & $70(21.4)$ & Carbamate & $\mathrm{NL}$ & 1B \\
\hline Paraquat & $62(19.02)$ & Bipyridil & $E$ & ॥ \\
\hline Glyphosate & $28(8.5)$ & Aminophosphonate & $E$ & III \\
\hline Fipronil & $27(8.2)$ & Phenylpyrazole & $\mathrm{NL}$ & $\|$ \\
\hline Glufosinate-ammonium & $18(5.52)$ & Phosphinates & C & $1 \mathrm{~B}$ \\
\hline Propaquizafop & $6(1.84)$ & Aryloxyphenoxypropionate & $\mathrm{NL}$ & $U$ \\
\hline Lindane & $2(0.61)$ & Organochlorine & $\mathrm{NL}$ & $\|$ \\
\hline Imidacloprid & $5(1.53)$ & Neonicotinoid & $E$ & ॥ \\
\hline Atrazine & $2(0.61)$ & Triazine & $\mathrm{NL}$ & III \\
\hline Chlorantraniliprole & $1(0.30)$ & Anthraminic diamides & $\mathrm{NL}$ & $U$ \\
\hline Acetochlor & $1(0.30)$ & Chloroacetanilides & B2 & III \\
\hline Fenbutatin oxide & $1(0.30)$ & Organotin & $E$ & III \\
\hline
\end{tabular}

U.S. EPA (Environmental Protection Agency)- Carcinogenecity Categorization: B2, Probable human carcinogen; C, Possible human carcinogen; $D$, Not classifiable as to human carcinogenicity; $E$, Evidence of not carcinogenicity for humans. NL, Not likely to be carcinogenic to humans. WHO (World Health Organization)classification of pesticides by hazard: IA, Extremely hazardous; IIB, Highly hazardous; II, Moderately hazardous; III, Slightly hazardous; U, Unlikely to present acute hazardous effect

\section{Results}

The most frequently used pesticides in La Cienega region The pesticides most used by farmers were terbufos (18.7\%), carbofuran (21.4\%), fipronil (8.2\%), and alphacypermethrin (3.6\%). The other pesticides had lower percentages of exposure, relative to total OPs which had $23.39 \%$ frequency (Table 1 ). It is noteworthy that some herbicides also had high frequency of use. These were paraquat (19.02\%) and glyphosate $(8.5 \%)$.

\section{Usage of the major pesticides and occupational exposure time}

After determining biomarkers of oxidative stress, the occupationally exposed group was divided into four subgroups based on the duration of exposure to pesticides: sub-group $\mathrm{A}$ comprised farmers who used pesticides up to 10 years (mean age 32 years); sub-group B farmers used pesticides up to 20 years (mean age 46 years); sub-group $C$ farmers used pesticides up to 30 years (mean age 53 years), while farmers in sub-group D were those who used pesticides for more than
30 years (mean age 62 years) (see Fig. 1). These subgroups show a higher percentage of men exposed in contrast to women (Table 2). In addition, this grouping confirmed that in the four sub-groups, there was high usage of pesticides, as was evident in long durations of exposure to terbufos (15 to 29 years), carbofuran (18 to 28 years), glyphosate (6 to 18 years), and paraquat (10 to 18 years). Although the farmers used other pesticides including phenylpyrazoles, the most commonly used ones were OPs and carbamates (Fig. 1).

\section{Oxidative stress markers in farmers and not-exposed subject}

There were statistically significant differences in values of oxidative stress markers between occupationally exposed and unexposed subjects, as shown in Table 3 .

In order to investigate whether the duration of use of pesticides affected oxidative stress biomarkers, average values of each oxidative stress marker in the not-exposed group was compared among the 4 exposure sub-groups (A, B, C and D). In all cases except glutathione redox 


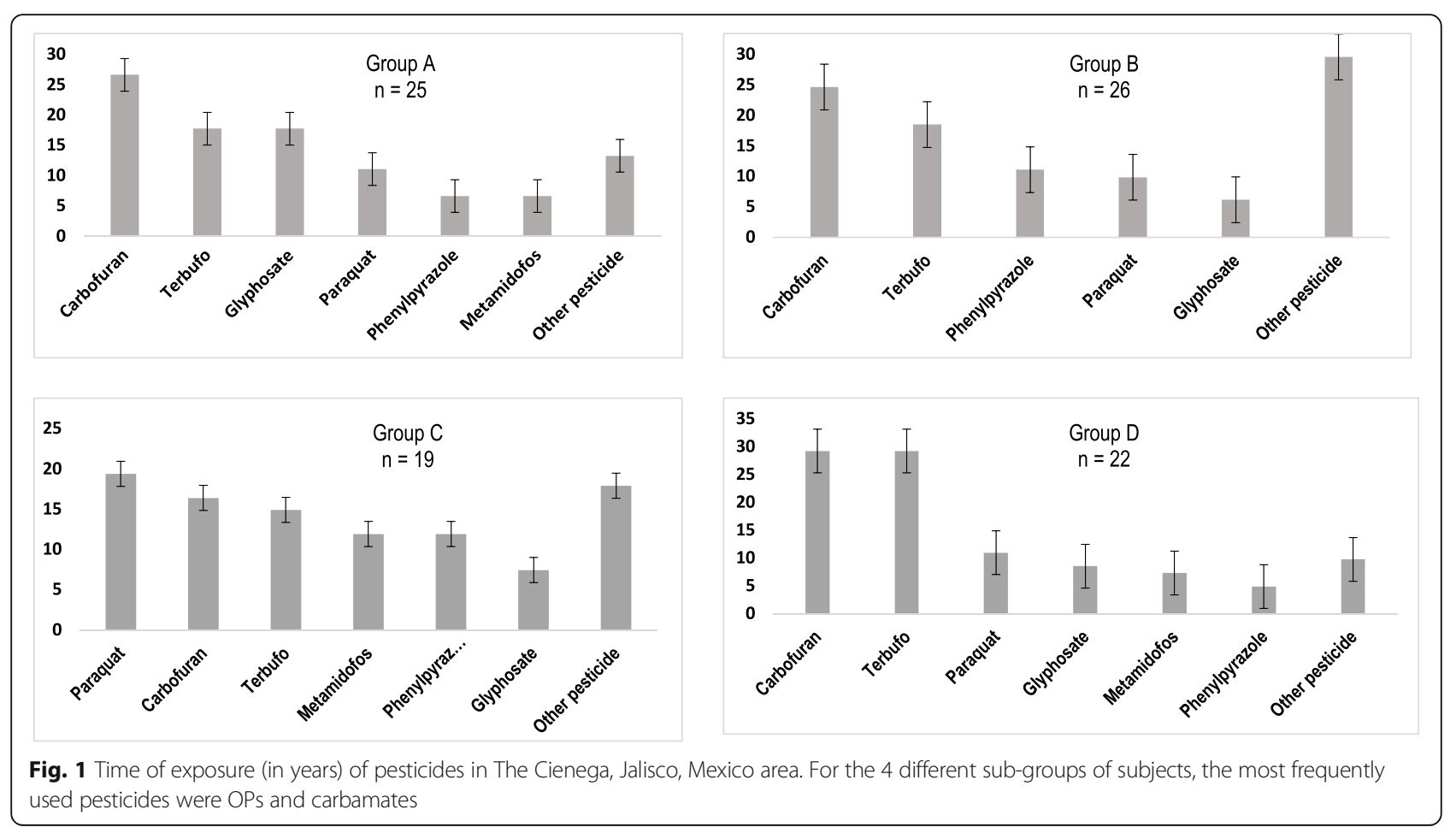

system, the unexposed group showed lower oxidative stress values than any of the 4 sub-groups (Table 4$)$. The same effect was observed on comparing markers between the exposed and unexposed groups (Table 3). Subsequent statistical analysis with ANOVA revealed that the 5 groups (one unexposed and 4 exposed) differed significantly except GSH/GSSG (Table 4).

Effect of pesticide exposure on glutathione redox system There were significant differences in GSH and GSSG levels between the not exposed group and the 4 exposed sub-groups $(p=0.000)$. This may be attributed to the not-exposure of the second group, since when subgroup A was compared with sub-group $\mathrm{B}, \mathrm{C}$ or $\mathrm{D}$, there were no significant differences $(p=0.963, p=0.980$ and $p=1.000$ respectively); nor were there any significant differences when sub-group B was compared against sub-group C $(p=1.000)$, B against D $(p=0.950)$, or subgroup $C$ against $\mathrm{D}(p=0.970)$. The $p$ values for GSSG levels have the similar statistical effect: there were differences only with the not exposed group, as shown in Table 4. GSH/GSSG ratio was not significant differences between the not exposed and the 4 exposed sub-groups $(p=0.710)$ as shown in Table 4.

Furthermore, a scatter plot of data for the not exposed group and four sub-groups of exposures showed that the not exposed group had consistently higher values for GSH and GSSG (average of 1.58 $\mu \mathrm{mMol} / \mathrm{mL}$ and $0.5221 \mu \mathrm{mMol} / \mathrm{mL}$, respectively), while the different subgroups showed lower values with less variability which implied significant differences in GSH and GSSG ( $p=0.000$; Fig. 2). GSH and GSSG results for subgroups A, B, C, D shown nearly values like a same point in contrast with scale versus not exposed group (Fig. 2). In other hand, GSH/ GSSG ratio show higher variability for the not exposed group and four sub-groups of exposures without significant differences ( $p=0.710$; Fig. 2).

\section{Effect of pesticide exposure on carbonyl levels and NO metabolites}

There were statistically significant differences in carbonyl levels and NO metabolites between the notexposed group and the 4 occupational exposure subgroups $(p=0.000)$. Moreover, there were significant

Table 2 Percentage of men and women in occupationally exposed subjects and not-exposed subjects

\begin{tabular}{llllll}
\hline & $\begin{array}{l}\text { Unexposed Group (\%) } \\
\boldsymbol{n = 9 3}\end{array}$ & $\begin{array}{l}\text { Group A (\%) } \\
\boldsymbol{n}=\mathbf{2 5}\end{array}$ & $\begin{array}{l}\text { Group B (\%) } \\
\boldsymbol{n}=\mathbf{2 6}\end{array}$ & $\begin{array}{l}\text { Group C (\%) } \\
\boldsymbol{n}=\mathbf{1 9}\end{array}$ & $\begin{array}{l}\text { Group D (\%) } \\
\boldsymbol{n}=\mathbf{2 2}\end{array}$ \\
\hline Male & 53.25 & 53.57 & 76 & 53.85 & 91.18 \\
Female & 46.75 & 46.43 & 24 & 46.15 & 8.82 \\
\hline
\end{tabular}


Table 3 Oxidative stress markers in occupationally exposed subjects and not-exposed subjects

\begin{tabular}{llll}
\hline Markers & $\begin{array}{l}\text { Subjects occupationally exposed } \\
\text { to pesticides }(\boldsymbol{n}=\mathbf{1 1 3})\end{array}$ & $\begin{array}{l}\text { Subjects occupationally not exposed } \\
\text { to pesticides }(\boldsymbol{n}=\mathbf{9 3})\end{array}$ & $\begin{array}{l}\boldsymbol{P} \text { value* } \\
\text { GSH }(\mu \mathrm{M})\end{array}$ \\
GSSG $(\mu \mathrm{M})$ & $0.0024 \pm 0.00155$ & $1.58 \pm 0.608$ & 0.0000 \\
GSH/GSSG ratio & $0.0011 \pm 0.00339$ & $0.5221 \pm 0.5900$ & 0.0000 \\
Carbonyl groups in proteins $(\mu \mathrm{mol} / \mathrm{mL})$ & $2.18 \pm 0.4572$ & $3.0262 \pm 1.0305$ & 0.581 \\
Nitrates-Nitrites $(\mu \mathrm{mol} / \mathrm{mL})$ & $62.7 \pm 35.70$ & $13.57 \pm 9.04$ & 0.0000 \\
Lipoperoxides & $55.62 \pm 55.26$ & $5.06 \pm 1.81$ & 0.0000 \\
(MDA-4HNE; $\mu \mathrm{mol} / \mathrm{mL})$ & $4.82 \pm 2.00$ & $1.59 \pm 0.88$ & 0.0000 \\
Membrane fluidity & & & 0.0000 \\
\hline
\end{tabular}

Data are presented as mean values \pm standard deviation

*Value obtained with the t-Student test for independent samples

differences in carbonyl levels when sub-group A was compared with sub-groups $\mathrm{B}$ and $\mathrm{D}(p=0.000$ and 0.054 , respectively), but not when sub-group A was compared with sub-group C $(p=0.999)$. Similarly, differences were found between sub-groups B and C $(p=0.000)$, and between sub-groups $\mathrm{C}$ and $\mathrm{D}(p=0.041)$, but not between sub-groups $\mathrm{B}$ and $\mathrm{D}(p=0.778)$. These results suggest that sub-groups $B$ and $D$ have higher values of carbonyl groups than sub-groups A and C (Fig. 3). Similarly, there were significant differences in NO metabolites of the four subgroups, when compared to not exposed group $(p=0.000)$, but not among the different sub-groups of exposed farmers. A plot of the distribution of carbonyl data for the not-exposed group and the 4 sub-groups of exposures revealed that the not-exposed group had lower values $($ mean $=13.5767 \mu$ moles $/ \mathrm{mL}$ ), while the 4 sub-groups showed greater variability and higher values (range of mean $=47.51$ to $80.05 \mu$ moles / $\mathrm{mL} ; p=0.000$; Fig. 3 ). The not exposed group had a low mean level of NO metabolites $(5.0627 \mu$ moles / mL), while the 4 subgroups had higher values (mean $=45.178$ to $63.015 \mu$ moles / mL; Fig. 3).

\section{Effect of pesticide exposure on lipid peroxidation (LPO) and membrane fluidity (MF)}

There were statistically significant differences in LPO and MF between the not-exposed group and the 4occupational exposure sub-groups $(p=0.000)$. These significant differences may be attributed to the not-exposure group, since when sub-group A was compared against sub-group $\mathrm{B}, \mathrm{C}$ or $\mathrm{D}$, there were no significant differences ( $p=0.346, p=1.000$ and $p=0.288$, respectively), nor were there significant differences when sub-group B was compared with sub-group $\mathrm{C}(p=0.534)$, or sub-group $\mathrm{C}$ against sub-group D $(p=0.242)$, but when sub-group B was compared with sub-group $\mathrm{D}$, there was significant difference $(p=0.003)$. In the plot of LPO data distribution for the not-exposed group and the 4 subgroups, the

Table 4 Oxidative stress markers in not-exposed subjects and occupationally exposed group

\begin{tabular}{|c|c|c|c|c|c|c|}
\hline & $\begin{array}{l}\text { Unexposed } \\
\text { Group } \\
(n=93)\end{array}$ & $\begin{array}{l}\text { Group A } \\
(n=25)\end{array}$ & $\begin{array}{l}\text { Group B } \\
(n=26)\end{array}$ & $\begin{array}{l}\text { Group C } \\
(n=19)\end{array}$ & $\begin{array}{l}\text { Group D } \\
(n=22)\end{array}$ & P-Value* \\
\hline $\mathrm{GSH}(\mu \mathrm{mol} / \mathrm{mL})$ & $1.58 \pm 0.6080$ & $0.0027 \pm 0.0019$ & $0.0023 \pm 0.0086$ & $0.0026 \pm 0.0017$ & $0.0026 \pm 0.0018$ & $\begin{array}{l}(F=126.20 \\
p=0.000)\end{array}$ \\
\hline GSSG $(\mu \mathrm{mol} / \mathrm{mL})$ & $0.5221 \pm 0.5900$ & $0.0007 \pm 0.0004$ & $0.0009 \pm 0.0034$ & $0.0006 \pm 0.0003$ & $0.0009 \pm 0.0005$ & $\begin{array}{l}(F=13.84 \\
p=0.000)\end{array}$ \\
\hline GSH/GSSG & $3.026 \pm 1.0305$ & $3.857 \pm 3.75$ & $2.555 \pm 2.52$ & $4.333 \pm 4.66$ & $2.888 \pm 2.6$ & $\begin{array}{l}(F=0.582, p= \\
0.710)\end{array}$ \\
\hline $\begin{array}{l}\text { Carbonyl groups in proteins ( } \mu \mathrm{mol} / \\
\mathrm{mL} \text { ) }\end{array}$ & $13.57 \pm 9.3$ & $49.44 \pm 25.62$ & $80.05 \pm 47.77$ & $47.51 \pm 15.95$ & $71.06 \pm 41.44$ & $\begin{array}{l}(F=48.63, p= \\
0.000)\end{array}$ \\
\hline Nitrates-Nitrites $(\mu \mathrm{mol} / \mathrm{mL})$ & $5.06 \pm 1.8$ & $59.06 \pm 55.33$ & $54.49 \pm 42.83$ & $63.01 \pm 75.09$ & $45.17 \pm 28.0$ & $\begin{array}{l}(F=22.78, p= \\
0.000)\end{array}$ \\
\hline $\begin{array}{l}\text { Lipoperoxides MDA-4HNE ( } \mu \mathrm{mol} / \\
\mathrm{mL} \text { ) }\end{array}$ & $1.59 \pm 0.89$ & $4.94 \pm 1.90$ & $4.22 \pm 1.23$ & $4.85 \pm 1.96$ & $5.80 \pm 2.16$ & $\begin{array}{l}(F=65.57, p= \\
0.000)\end{array}$ \\
\hline Membrane fluidity & $0.14 \pm 0.04$ & $0.49 \pm 0.03$ & $0.49 \pm 0.04$ & $0.47 \pm 0.02$ & $0.49 \pm 0.05$ & $\begin{array}{l}(F=694.84, p= \\
0.000)\end{array}$ \\
\hline
\end{tabular}

Data are presented as mean values \pm standard deviation

*Value obtained with the one-way ANOVA. The comparison was made between the unexposed group and subgroups A, B, C and D, for each oxidative stress marker 

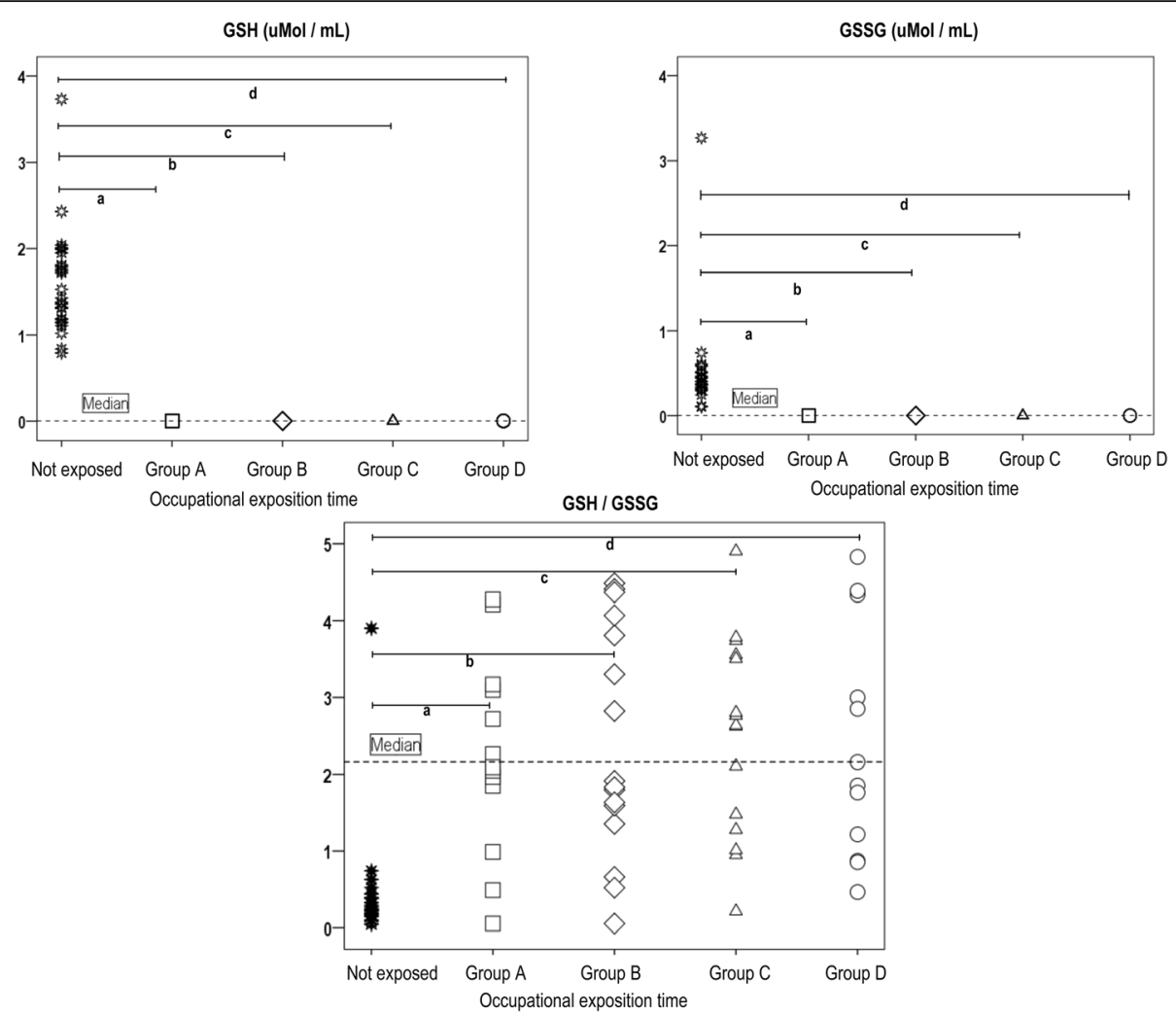

Fig. $2 \mathrm{GSH}(\mu \mathrm{Mol} / \mathrm{mL})$ and GSSG ( $\mu \mathrm{Mol} / \mathrm{mL}$ ) levels and GSH/GSSG ratio in groups of occupational exposure and not exposed group. GSH and GSSG results for subgroups $A, B, C, D$ shown nearly values in the scale for which it is observed as a single point in the graph. $p$ values were obtained with a one-way ANOVA test at $95 \%$ confidence level. The significance value is shown for the comparison of the unexposed group with the four occupational exposure subgroups of GSH and GSSG $(a, b, c, d ; p=0.000)$, and for the GSH / GSSG ratio $(a, b, c, d ; p=0.710)$

former showed lower values (mean $=1.5999 \mu \mathrm{mol} / \mathrm{mL}$ ), when compared to the exposure sub-groups $(4.2244$ to $5.8014 \mu \mathrm{mol} / \mathrm{mL})$, indicating statistical difference $(p=$ 0.000; Fig. 3). For MF (Ie / Im), the not-exposed group had lower values (mean $=0.1453$ ), but sub-groups $\mathrm{A}, \mathrm{B}, \mathrm{C}$ and $\mathrm{D}$ had much higher values (mean ranging from 0.4782 to 0.4975 ) ( $p=0.000$; Fig. 3 ). There were no significant changes in the 4 sub-groups.

\section{Discussion}

The most commonly used pesticides in La Cienega region The significant differences in levels of oxidative stress markers between the occupationally exposed and not exposed subjects, and between the not-exposed group and the 4 exposure sub-groups may be due to the imbalance in the oxidant/antioxidant system. Participants in this study had chronic exposure mainly to OPs, carbamates, glyphosate and paraquat, wich they handled with minimal protection with a high dermal and inhalation exposure mainly. These findings are alarming because the region lacks toxicological studies that reveal the impact on farmer's health. In addition, carbamate [23, 34, 35] and OPs [24, 27, 36] exposure increases levels of oxidative stress markers in both murine and human models. In different agricultural areas of Mexico the use of highly hazardous pesticides had negative effects on farm workers and their families, especially children [37, 38]. The General Bureau of Epidemiology, Ministry of Health, Jalisco, Mexico, has stated that between 2014 and 2018, there were approximately 76 cases of pesticide poisoning per annum in La Cienega, Jalisco area. This is equivalent to pesticide poisoning every 5 days. In Jalisco, México; the municipalities most adversely affected were La Barca (162 cases), Jocotepec (77 cases), Ocotlán (50 cases), Atotonilco el Alto (19 cases), and Tototlán (18 cases).

\section{Effect of pesticides on glutathione redox system}

Significant differences were found in GSH and GSSG levels between the not exposed group and 4 occupational exposure sub-groups, indicating oxidative stress. A decrease in GSH/GSSG was observed as a result of exposure to OPs, carbamates and paraquat $[7,9,23,24$, 

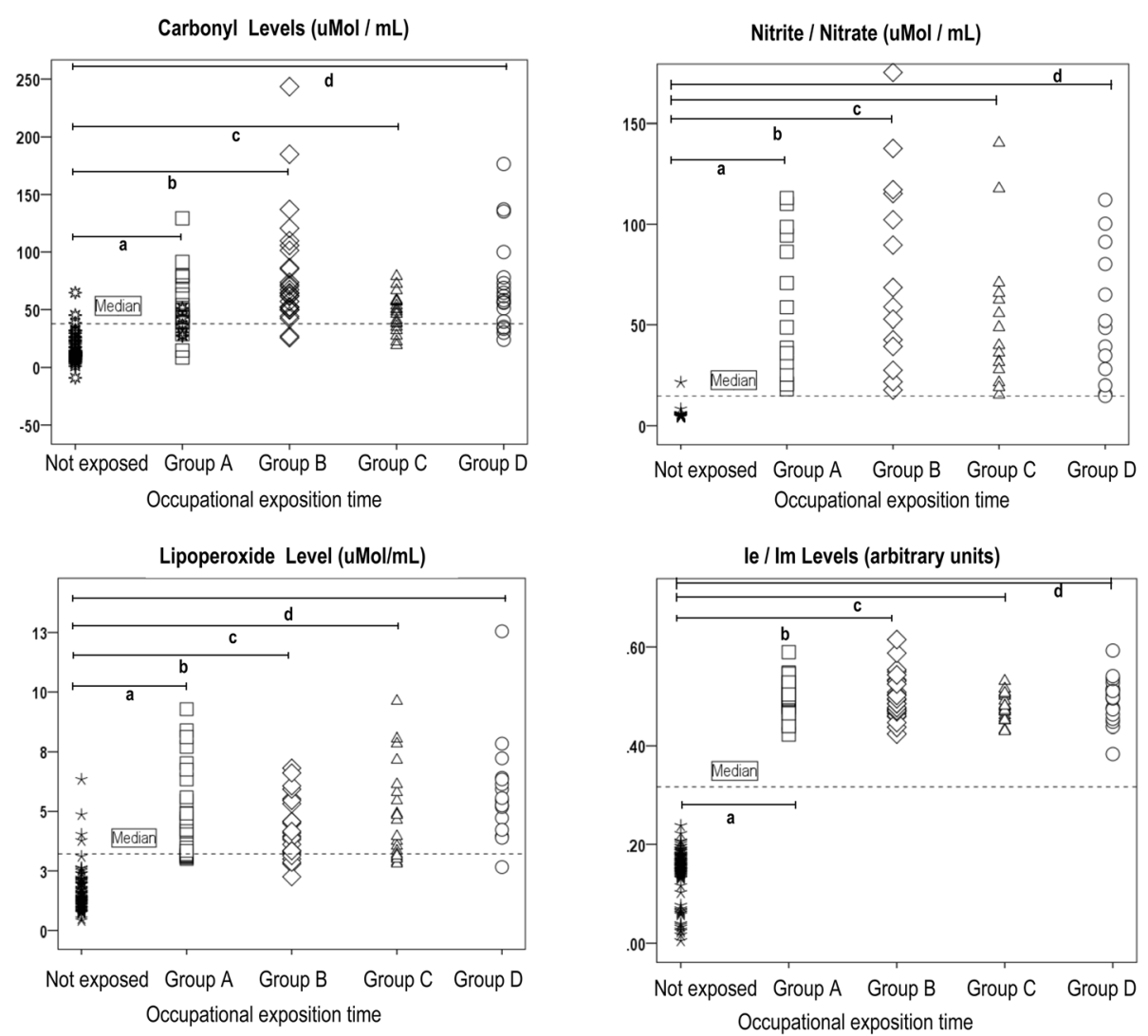

Fig. 3 Carbonyl levels, nitrate-nitrite metabolites, LPO, and membrane fluidity levels in groups of exposed to OPs and not exposed group. The $p$ values were obtained with a one-way ANOVA test at 95\% confidence level. The significance value for the comparison between the unexposed group with the four occupational exposure subgroups $A, B, C$ and $D(a, b, c, d p=0.000)$ is show

27, 39-41]. However, unlike our results, studies that have analyzed GSH and GSSG specifically in erythrocytes after exposure to OPs (as was done in the present study) reported high levels [42, 43]. Particularly, differences in the GSH and GSSG responses depend not only on the type of sample analyzed, but also the type of OPs involved, and the duration of exposure [42].

The higher values to GSH and GSSG in the not exposed group, suggests that exposure to pesticides (regardless of the duration in years of use) affects human health, since the only group that maintained its functional antioxidant activity was not exposed group. On the other hand, the low levels of GSH and GSSG markers in exposed subgroups may be due to the low antioxidant defense induced by chronic exposure to pesticides, as reported by Spodniewska et al. [42] and Georgiadis et al. [43]. Conversely, other studies show that pesticide exposure may increase the GR activity, which converts GSSG to GSH, as an adaptation of the organism to prevent permanent oxidative damage [26, 34, 41]. However, our study showed that the levels of GSH and GSSG decrease significantly despite the previous evidence shown. Therefore, the observed decrease in both GSH and GSSG could be more important than the GSH/GSSG ratio for very low values.

\section{Effect of pesticides on carbonyl levels and NO metabolites}

Sub-groups B and D had higher levels of carbonyls, when compared to sub-groups $\mathrm{A}$ and $\mathrm{C}$. This may be due to oxidative deamination in response to the increased oxidative stress $[16,44,45]$. It was observed that the main pesticides to which sub-groups $B$ and $D$ were exposed were terbufos and carbofurans (OPs and carbamate, respectively; Fig. 1). Studies have demonstrated that exposure of porcine oocytes to $750-1000 \mu \mathrm{M}$ of malathion (OPs) for $44 \mathrm{~h}$ increased protein oxidation and levels of carbonyls concentration [44]. In another study, exposure of rats to dichlorvos (OPs) at a dose of $47 \mathrm{mg} / \mathrm{kg}$ led to increases in carbonyls up to $95 \%$ higher than those of not exposed group [45]. Carbamate (carbofuran) exposure produces changes in carbonyls similar to those of OPs exposure, as revealed when young rats were exposed to these substances [46]. In this regard, 
Cattelan et al. have reported a significant increase in carbonyls in farmers exposed to carbamate-type pesticides [26]. The previous evidence is consistent with the results presented in Table 3, where a 4.5 -fold increase in the formation of carbonyl groups of subjects exposed to pesticides versus subjects without occupational exposure is revealed $(p=0.000)$. Similarly, for NO metabolites, significant differences were observed among the 4 subgroups, relative to the not exposed group, but not between the different exposure sub-groups. It is known that an increase in LPO levels goes together with an increase in NO metabolites [47]. The results of this study showed significant increases in $\mathrm{NO}_{2}{ }^{-} / \mathrm{NO}_{3}{ }^{-}$levels. These results agree with those obtained in previous studies on OPs (diazinon and chlorpyrifos) in which increases in nitrate/nitrite levels were reported in rats [48, 49]. Regarding occupational exposure to carbamates, studies have demonstrated that carbamate induces nitric oxide synthase, which results in increases in the levels of $\mathrm{NO}_{3}{ }^{-}$and $\mathrm{NO}_{2}{ }^{-}$, along with enhancement of lipid peroxidation, and increases in levels of protein carbonyls groups $[9,50,51]$ as seen in our results.

\section{Effect of pesticides on LPO and MF}

The increase in LPO in the 4-occupational exposure sub-groups, especially in sub-group D relative to subgroup B may be related to increases in MDA and 4HNE values with a longer exposure time to pesticides. This may be due to the fact that increased LPO levels were particularly associated with frequency of occupational exposure of terbufos (18.52 and 29.26\%, B and D groups respectively) and carbamates (24.7 and $29.27 \%$, B and $\mathrm{D}$ groups respectively) as shown in Fig. 1 . The increase in LPO may be a response to the cholinergic hyperactivity which increased ROS and RNS production by both pesticides [21, 22, 50]. Similarly, exposure to pesticides generates $\mathrm{H}_{2} \mathrm{O}_{2}$ and $\mathrm{OH}^{-}$radicals which produce peroxylipid radical (LOO.), and lipid-alkoxyl (LO.) radical which, on cyclization and reduction, give rise to MDA, 4-HNE and acrolein [16]. The increase in LPO with respect to the not exposed group is consistent with the reports of various researchers [27, 34-36].

Moreover, terbufos and carbamates are lipophilic molecules with high affinity for the plasma membrane [52], thereby inducing increased peroxidation [21, 22, 44, 51] and decreased membrane fluidity [21]. Studies by Rai et al. [51], Dhouib et al. [9], and Liu et al. [23], reported that exposure to carbamate increased levels of ROS and RNS, and decreased membrane fluidity. However, in this study, results showed a three-fold increase in membrane fluidity over the not exposed group, while among the 4 sub-groups, there were no significant variations in membrane fluidity. These data of membrane fluidity were unexpected. Interestingly, the effect of some insecticides on membrane fluidity depends on the cholesterol content [53]. Thus, a quantitative analysis of membrane lipids should be necessary to define this effect.

\section{Conclusion}

La Cienega, Jalisco, Mexico is an important agricultural zone because of the economic impulse for the country. So, the use of pesticides is a common practice. In our results, the main pesticides used in the region are OPs, carbamates, glyphosate and paraquat with a high dermal and inhalation exposure, mainly. Particularly, exposure to OPs and carbamates shown an increase in levels of carbonyl groups, $\mathrm{NO}_{2}^{-} / \mathrm{NO}_{3}^{-}$, lipoperoxidation and high mitochondrial membrane fluidity, as well as a decrease in the concentration of GSH and GSSG in exposed farmers versus the not exposed group. When evaluating groups A, B, $\mathrm{C}$ and $\mathrm{D}$ (intragroups) by years of exposure, a slight increase in oxidative markers and membrane fluidity were observed in those with more than 21 years of pesticide use (groups $\mathrm{C}$ and $\mathrm{D}$ ), although it should be noted that it was not statistically significant analysis between groups. The increase in the oxidation levels that are found in farmers with occupational exposure constitute a theoretical basis on which to explain the high prevalence in the Cienega, Jalisco for neurodegenerative disease and cancer projected in future studies.

\section{Abbreviations \\ ROS: Reactive oxidant species; GR: Glutathione reductase; GSSG: Oxidized glutathione; GSH: Reduced glutathione; GPx: Glutathione peroxidase; \\ OPs: Organophosphorus; $\mathrm{H}_{2} \mathrm{O}_{2}$ : Hydrogen peroxide; $\mathrm{OH}^{-}$: Hydroxyl radical; RNS: Reactive nitrogen species; $\mathrm{O}_{2}^{-}$: Superoxide anion; NO: Nitric oxide; $\mathrm{ONOO}^{-}$: Peroxynitrite; $\mathrm{NO}_{2}^{-}$: Nitrite; $\mathrm{NO}_{3}^{-}$: Nitrate; PUFAs: Polyunsaturated fatty acids; MDA: Malondialdehyde; 4-HNE: 4-hydroxyalkene; AChE: Enzyme acetylcholinesterase; NMDA: N-methyl-D-aspartate; EDTA: Ethylene diamine tetra acetic acid; NADPH: Nicotinamide Adenine Dinucleotide Phosphate; DiPP: 1,3 dipyrylpropane; LPO: Lipid peroxidation; MF: Membrane fluidity; LOO: Peroxylipid radical; LO: Lipid-alkoxyl; SFAs: Saturated free fatty acids}

\section{Acknowledgments}

We thank José Guadalupe Ruiz Vázquez, MD, Surgeon, for his support and supervision in the application of the surveys of the participants in this study.

\section{Authors' contributions}

Salazar-Flores J and Pacheco-Moises F critically revised manuscript for important intellectual content and contributed to interpretation of data, Ortiz G and Torres-Jasso J contributed to acquisition and analysis of data and drafted manuscript, Romero-Renteria O. and Briones-Torres A contributed to acquisition and analysis of data, Torres-Sánchez E and Salazar-Flores I contributed to conception of the study, beside Torres-Sánchez E contributed to acquisition and interpretation data and critically revised manuscript. All the authors gave final approve and agree to be accountable for all aspects of the work in ensuring that question relating to the accuracy or integrity of any part of the work are appropriately investigated and resolved.

\section{Funding}

This work was funded by the Department of Academic Improvement (DAS), Secretary of Public Education (SEP) in Mexico (DAS-511-6/18-9169).

\section{Availability of data and materials}

The databases used during the current study are available from the corresponding author on reasonable request. 


\section{Ethics approval and consent to participate}

This project was approved by the Ethics Committee of the University Center of La Cienega, University of Guadalajara (Folio 2017-037). Each participant signed an informed consent letter guaranteeing the confidentiality of data. The study was carried out in strict compliance with the principles of the Declaration of Helsinki.

\section{Consent for publication}

Not applicable.

\section{Competing interests}

No conflict of interest is associated with this work.

\section{Author details}

'Department of Medical Sciences and Life, CUCIENEGA, University of Guadalajara, Ocotlan, Jalisco, Mexico. ${ }^{2}$ Department of Chemistry, CUCEI, University of Guadalajara, Guadalajara, Jalisco, Mexico. ${ }^{3}$ Department of Philosophical and Methodological Discipline, CUCS, University of Guadalajara Guadalajara, Jalisco, Mexico. ${ }^{4}$ Department of Biological Sciences, CUCOSTA, University of Guadalajara, Puerto Vallarta, Jalisco, Mexico.

\section{Received: 19 November 2019 Accepted: 18 October 2020}

\section{Published online: 28 October 2020}

\section{References}

1. Rahman I, Biswas SK, Kode A. Oxidant and antioxidant balance in the airways and airway diseases. Eur J Pharmacol. 2006;533:222-39. https://doi. org/10.1016/j.ejphar.2005.12.087.

2. Dumitrescu L, Popescu-Olaru J, Cozma L, Tulba D, Hinescu ME, Ceafalan LC, Gherghiceanu M, Popescu BO. Oxidative stress and the microbiota-gut-brain axis. Oxidative Med Cell Longev. 2018;2018:2406594. https://doi.org/10.1155/ 2018/2406594

3. Ighodaro OM, Akinloye OA. First line defence antioxidants-superoxide dismutase (SOD), catalase (CAT) and glutathione peroxidase (GPX): their fundamental role in the entire antioxidant defence grid. Alexandria J Med. 2018:54:287-93. https://doi.org/10.1016/i.ajme.2017.09.001.

4. Ohja A, Srivastana N. Redox imbalance in rat tissues exposed with organophosphate pesticides and therapeutic potential of antioxidant vitamins. Ecotoxicol Environ Saf. 2012;75(1):230-41. https://doi.org/10.1016/j. ecoenv.2011.08.013.

5. Saeedi SSS, Shokrzadeh M. Role of pesticides in human life in the modern age: a review. In: Stoytcheva M, editor. Pesticides in the modern world. Baja California: IntechOpen; 2011. p. 3. https://doi.org/10.5772/18827.

6. Westcott ND. Terbufos residues in wheat and barley. J Environ Sci Health B. 1998:23(4):317-30. https://doi.org/10.1080/03601238809372608.

7. D'Souza UJA. Pesticide toxicity and oxidative stress: a review. Borneo J Med Sci. 2017;11(1):9-19 https://jurcon.ums.edu.my/ojums/index.php/bjms/ article/view/466.

8. Li JT, Sheng SJ, Du XL. Metabolism of terbufos in rat liver. J Occup Heatlh. 1999;41:62-8 https://pdfs.semanticscholar.org/ae0f/da6e90a768df937d39b34 a0fabc824a91739.pdf.

9. Dhouib IB, Annabi A, Jallouli M, Marzouki S, Gharbi N, Elfazaa S, Montassar ML. Carbamates pesticides induced immunotoxicity and carcinogenicity in human: a review. J Appl Biomed. 2016;14(2):85-90. https://doi.org/10.1016/j. jab.2016.01.001.

10. Coban FK, Ince S, Kucukkurt I, Demirel HH, Hazman O. Boron attenuates malathion-induced oxidative stress and acetylcholinesterase inhibition in rats. Drug Chem Toxicol. 2015;38(4):391-9. https://doi.org/10.3109/01480545. 2014.974109.

11. Imran H, Dilshad KA. Adverse health effects of pesticide exposure in agricultural and industrial workers of developing country. In: Stoytcheva M, editor. Pesticides, the impacts of pesticides exposure. Baja California: IntechOpen; 2011. p. 155. https://doi.org/10.5772/13835.

12. Coronado M, Vega y León HS, Gutiérrez R, Vazquez F, Radilla CV. Antioxidantes: perspectiva actual para la salud humana. Rev Chil Nutr. 2015; 42(2):206-12. https://doi.org/10.4067/S0717-75182015000200014.

13. Nita M, Grzybowski A. The role of the reactive oxygen species and oxidative stress in the pathomechanism of the age-related ocular diseases and other pathologies of the anterior and posterior eye segments in adults. Oxidative Med Cell Longev. 2016:3164734. https://doi.org/10.1155/2016/3164734.
14. Imai H, Nakagawa Y. Biological significance of phospholipid hydroperoxide glutathione peroxidase (PHPGX, GPx4) in mammalian cells. Free Radic BiolMed. 2003;34(2):145-69. https://doi.org/10.1016/s0891-5849(02)01197-8.

15. Beckman JS, Koppenol WH. Nitric oxide, superoxide, and peroxynitrite: the good, the bad and ugly. Am J Phys. 1996;271(5):1424-37. https://doi.org/10. 1152/ajpcell.1996.271.5.C1424.

16. Frijhoff J, Winyard PG, Zarkovic N, Davies SS, Stocker R, Cheng D, Knight AR, Taylor EL, Oettrich J, Ruskovska T, Gasparovic AC, Cuadrado A, Weber D, Poulsen HE, Grune T, Schmidt HH, Ghezzi P. Clinical relevance of biomarkers of oxidative stress. Antioxid Redox Signal. 2015;23(14):1144-70. https://doi. org/10.1089/ars.2015.6317.

17. Tsikas D. Assessment of lipid peroxidation by measuring malondialdehyde (MDA) and relatives in biological samples: analytical and biological challenges. Anal Biochem. 2017;524:13-30. https://doi.org/10.1016/j.ab.2016. 10.021 .

18. Gaschler MM, Stockwell BR. Lipid peroxidation in cell death. Biochem Biophys Res Commun. 2017;482(3):419-25. https://doi.org/10.1016/j.bbrc 2016.10 .086

19. Ibarguren M, Lopez DJ, Escriba PV. The effect of natural and synthetic fatty acids on membrane structure, microdomain organization, cellular functions and human health. Biochim Biophys Acta. 2014;1838(6):1518-28. https://doi. org/10.1016/j.bbamem.2013.12.021.

20. Kehrer JP, Klotz LO. Free radicals and related reactive species as mediators of tissue injury and disease: implications for health. Crit Rev Toxicol. 2015; 45(9):765-98. https://doi.org/10.3109/10408444.2015.1074159.

21. Pearson JN, Patel $M$. The role of oxidative stress in organophosphate and nerve agent toxicity. Ann N Y Acad Sci. 2016;1378(1):17-24. https://doi.org/ 10.1111/nyas.13115.

22. Vanova N, Pejchal J, Herman D, Dlabkova A, Jun D. Oxidative stress in organophosphate poisoning: role of standard antidotal therapy. J Appl Toxicol. 2018;38(8):1058-70. https://doi.org/10.1002/jat.3605

23. Liu H, Cui B, Xu Y, Hu C, Liu Y, Qu G, Li D, Wu Y, Zhang D, Quan S, Shi J. Ethyl carbamate induces cell death through its effects on multiple metabolic pathways. Chem Biol Interact. 2017;277:21-32. https://doi.org/10. 1016/j.cbi.2017.08.008

24. Tsukamoto M, Tampo Y, Sawada M, Yonaha M. Paraquat-induced oxidative stress and dysfunction of the glutathione redox cycle in pulmonary microvascular endothelial cells. Toxicol Appl Pharmacol. 2002;178(2):82-92. https://doi.org/10.1006/taap.2001.9325.

25. Jalisco State Development Plan. Plan de Desarrollo de la Región Ciénega 2015-2025; 2015. p. 40

26. Cattelan MDP, Maurer P, Garcia F, Berro LF, Machado MM, Manfredini V, Piccoli JDCE. Occupational exposure to pesticides in family agriculture and the oxidative, biochemical and hematological profile in this agricultural model. Life Sci. 2018;203:177-83. https://doi.org/10.1016/j.Ifs.2018.04.038.

27. Ahmadi N, Mandegary A, Jamshidzadeh A, Mohammadi-Sardoo M, Mohammadi-Sardoo M, Salari E, Pourgholi L. Hematological abnormality, oxidative stress, and genotoxicity induction in the greenhouse pesticide sprayers; investigating the role of NQO1 gene polymorphism. Toxics. 2018; 6(1):1-15. https://doi.org/10.3390/toxics6010013.

28. El-Bini I, Lasram MM, Annabi A, Gharbi N, El-Fazaa S. A comparative study on toxicity induced by carbosulfan and malathion in Wistar rat liver and spleen. Pestic Biochem Physiol. 2015;124:21-8. https://doi.org/10.1016/j. pestbp.2015.03.012.

29. Griffith OW. Determination of glutathione and glutathione disulfide using glutathione reductase and 2-vinylpyridine. Anal Biochem. 1980;106(1):2017212. https://doi.org/10.1016/0003-2697(80)90139-6.

30. Levine RL, Garland D, Oliver CN, Amici A, Climent I, Lenz AG, Ahn BW, Shaltiel S, Stadtman ER. Determination of carbonyl content in oxidatively modified proteins. Methods Enzymol. 1990;186:464-78. https://doi.org/10. 1016/0076-6879(90)86141-h.

31. Ghasemi A, Hedayati M, Biabani M, Khoushbaten A, ASgari AR. Comparing deproteinization methods for serum nitric oxide assay by Greiss reaction. $J$ Med Sci Res. 2018;2:29 https://www.sid.ir/en/journal/NiewPaper.aspx?id=95891.

32. Ortiz GG, Pacheco-Moisés F, Hafidi ME, Jiménez-Delgado A, Macias-Islas MA, Rosales Corral SA, de la Rosa AC, Sánchez-González VJ, Arias-Merino ER, Velázquez-Brizuela IE. Detection of membrane fluidity in submitochondrial particles of platelets and erythrocyte membranes from Mexican patients with Alzheimer disease by intramolecular excimer formation of 1,3 dipyrenylpropane. Dis Markers. 2008;24(3):151-6. https://doi.org/10.1155/ 2008/642120. 
33. SPSS Inc. Released. SPSS for Windows, version 19.0. Chicago: SPSS Inc; 2010.

34. Lozano-Paniagua D, Parrón T, Alarcón R, Requena M, Gil F, López-Guarnido $O$, Lacasaña M, Hernandez AF. Biomarkers of oxidative stress in blood of workers exposed to non-cholinesterase inhibiting pesticides. Ecotoxicol Environ Saf. 2018;162:121-8. https://doi.org/10.1016/j.ecoenv.2018.06.074.

35. Ogut S, Gultekin F, Kisioglu AN, Kucukoner E. Oxidative stress in the blood of farm workers following intensive pesticide exposure. Toxicol Ind Health. 2011;27(9):820-5. https://doi.org/10.1177/0748233711399311.

36. Jalilian H, Neghab M, Tatar M, Taheri S. Respiratory and dermal symptoms and raised serum concentrations of biomarkers of oxidative stress among pesticide retailers. Int J Occup Environ Med. 2018;9(4):194-204. https://doi. org/10.15171/ijoem.2018.1417.

37. Garcia-Hernandez J, Leyva MJB, Martinez RIE, Hernández MIO, Aldana MLM, Rojas AEG, Betancourt ML, Perez NEH, Perera JHR. Estado actual de la investigación sobre plaguicidas en México. Rev Int Contam Ambie. 2018;34: 29-60. https://doi.org/10.20937/RICA.2018.34.esp01.03.

38. González-Arias CA, Robledo-Marenco ML, Medina-Díaz IM, VeazquezFernandez JB, Giron-Perez MI, Quintanilla-Vega B, Ostrosky-Wegman P, Perez-Herrera NE, Rojas-Garcia AE. Pattern of use and sale of pesticides in Nayarit, Mexico. Rev Int Contam Ambient. 2010;26(3):29-60 http://www. scielo.org.mx/scielo.php?script=sci_arttext\&pid=\$018849992010000300005 \&lng=es\&tlng=es.

39. Eid RA. Apoptosis of rat renal cells by organophosphate pesticide, quinalphos: ultrastructural study. Saudi J Kidney Dis Transpl. 2017;28(4):72536 http://www.sjkdt.org/text.asp?2017/28/4/725/211330.

40. Djukic MM, Jovanovic MD, Ninkovic M, Stevanovic I, llic K, Curcic M, Vekic J. Protective role of glutathione reductase in paraquat induced neurotoxicity. Chem Biol Interact. 2012;199(2):74-86. https://doi.org/10.1016/j.cbi.2012.05.008.

41. Maran E, Fernandez M, Barbieri P, Font G, Ruiz MJ. Effects of four carbamate compounds on antioxidant parameters. Ecotoxicol Environ Saf. 2009;72(3): 922-30. https://doi.org/10.1016/j.ecoenv.2008.01.018.

42. Spodniewska A. Glutathione and glutathione-related enzymes in rats exposed to dimethoate and/or pyrantel. Pol J Vet Sci. 2014;17(1):105-12 https://www.ncbi.nlm.nih.gov/pubmed/24724477.

43. Georgiadis G, Mavridis C, Belantis C, Zisis IE, Skamagkas I, Fragkiadoulaki I, Heretis I, Tzortzis V, Psathakis K, Tsatsakis A, Mamoulakis C. Nephrotoxicity issues of organophosphates. Toxicology. 2018;407:129-36. https://doi.org/10. 1016/j.tox.2018.07.019.

44. Flores D, Souza V, Betancourt M, Teteltitla M, González-Márquez H, Casas E, Bonilla E, Ramírez-Noguera P, Gutiérrez-Ruiz MC, Ducolomb Y. Oxidative stress as a damage mechanism in porcine cumulus-oocyte complexes exposed to malathion during in vitro maturation. Environ Toxicol. 2017; 32(6):1669-78. https://doi.org/10.1002/tox.22384.

45. Dileepkumar HV, Ritesh KR. Dichlorvos induces differential oxidative stress in the brain regions of rat. Adv Pharmac J. 2018;3(5):150-6. https://doi.org/10. 31024/apj.2018.3.5.3.

46. Martin-Reina J, Duarte JA, Cerrillos L, Bautista JD, Moreno I. Insecticide reproductive toxicity profile: organophosphate, carbamate and pyrethroids. J Toxins. 2017;4(1):7 http://www.avensonline.org/fulltextarticles/JTOX-2328-1 723-04-0019.html.

47. Berlett BS, Stadtman ER. Protein oxidation in aging, disease and oxidative stress. J Biol Chem. 1997;272(33):20313-6. https://doi.org/10. 1074/jbc.272.33.20313.

48. Beydilli H, Yilmaz N, Cetin ES, Topal Y, Celik Ol, Sahin C, Topal H, Cigerci $\mathrm{IH}$, Sozen $\mathrm{H}$. Evaluation of the protective effect of silibinin againts Diazinon induced hepatotoxicity and free-radical damage in rat liver. Iran Red Crescent Med J. 2015;17(4):25310. https://doi.org/10.5812/ ircmj.17(4)2015.25310

49. Yildirim E, Baydan E, Kanbur M, Kul O, Cinar M, Ekici H, Atmaca N. The effect of chlorpyrifos on isolated thoracic aorta in rats. BioMed Res Int. 2013: 376051. https://doi.org/10.1155/2013/376051.

50. Kamboj A, Kiran R, Sandhir R. Carbofuran-induced neurochemical and neurobehavioral alterations in rats: attenuation by $\mathrm{N}$-acetylcysteine. Exp Brain Res. 2006;170(4):567-75. https://doi.org/10.1007/s00221-005-0241-5.

51. Rai DK, Sharma B. Carbofuran-induced oxidative stress in mammalian brain. Mol Biotechnol. 2007;37(1):66-71 https://www.ncbi.nlm.nih.gov/ pubmed/17914167.

52. Amara IB, Soudani N, Troudi A, Hakim A, Zeghal KM, Boudawara T, Seghal N. Dimethoate induced oxidative damageand histopathological changes in lung of adult rats: modulatory effects of selenium and/or vitamin E. Biomed Environ Sci. 2018;25(3):340-51. https://doi.org/10.3967/0895-3988.2012.03.013.

53. Blasiak J. Changes in membrane fluidity evoked by organophosphorus insecticide bromfenvinfos and its methylated analogue. Comp Biochem Physiol C Pharmacol Toxicol Endocrinol. 1995;110(1):15-21. https://doi.org/ 10.1016/0742-8413(94)00082--.

\section{Publisher's Note}

Springer Nature remains neutral with regard to jurisdictional claims in published maps and institutional affiliations.

\section{Ready to submit your research? Choose BMC and benefit from:}

- fast, convenient online submission

- thorough peer review by experienced researchers in your field

- rapid publication on acceptance

- support for research data, including large and complex data types

- gold Open Access which fosters wider collaboration and increased citations

- maximum visibility for your research: over $100 \mathrm{M}$ website views per year

At $\mathrm{BMC}$, research is always in progress.

Learn more biomedcentral.com/submissions 